\section{Harinadh Vemaaboina}

Associate Professor Nalla Narasimha Group of Institutions Faculty of Mechanical Engineering India

Suresh Akella

Professor, Sreyas Institute of Engineering and Technology Faculty of Mechanical Engineering India

\section{Ramesh Kumar Buddu}

Scientist-F Institute of Plasma Research
Distortion Control in Laser Beam Welding using Taguchi ANOVA Analysis

Industrial process control is essential as the customer demand for quality, cost, performance; safety and reliability are ever-increasing. To obtaining a process that will give minimum distortion after laser welding using orthogonal array experimentation a fractional factorial method. Nine controlled randomized experiments of laser welding were done using three parameters; Laser power, welding speed and Argon flow rate. Each of these factors had three degrees of freedom and the fractional factorial experimentation was analyzed to find the best combination of levels in control parameters of the output, lower the better, LB, distortion. Simple inspection methods, No-way ANOVA, Linear Figures, ANOVA and Pooled ANOVA, were used, and two parameters were identified to be critical, welding speed at 31\% and Argon Flow rate at $68 \%$ contribution with a statistical confidence of about $90 \%$ to $95 \%$. The third factor of power was set to minimum cost level as it was found to be an insignificant factor for distortion control. Various aspects of the Taguchi method [15] were used to make the analysis useful for designers and engineers to use the results. Confirmation interval, process capability and tolerance design were calculated.

Keywords: Design of experiments, Laser beam welding, distortion, Taguchi Analysis, ANOVA.

\section{INTRODUCTION}

Welding is a skill and art very commonly used joining process in building structures and mechanical parts. However, its importance as science grows when it is evaluated from the assembly of parts, reliability and safety of structures as in boilers, turbines and especially, in nuclear reactors as even a small part failure can cause national disaster and loss. It is from this point of view that a theoretical scientific look of the trial process of experiments, laser beam experiments are conducted before actual manufacturing of nuclear reactors to see the process parameters of importance. Subashini [1] had studied the weldability with single-pass $\mathrm{CO}_{2}$-MIG Laser Welding process of maraging steel thick plate. The studies include the microstructure and mechanical properties of the weldments and also simulated the distribution of HAZ in the weldments. Laser keyhole process of IPG YLR-4000 was used to study the effect of heat input in weld bead width for SS2205 with DOE for $6 \mathrm{~mm}$ thick plate, two Stochastic Kriging and kriging methods are used to compare the results [2]. Lung Kwang Pan [3] has applied the Taguchi method of Analysis to an Nd: YAG laser for thin plate welding. The material composition magnesium alloy butt welding was optimized using the Taguchi method. The output tensile strength of weld material was the output

Received: April 2019, Accepted: October 2019

Correspondence to: Vemanaboina Harinadh

Faculty of Mechanical Engineering,

NNRG, Hyderabad, 500088, India.

E-mail: vharinadh@outlook.com parameter governing the laser beam in thin plate butt welding. The factors can be the shielding gas, laser energy, the speed of workpiece, the point at which the laser is focused, pulse frequency, and pulse shape. An optimum parameter combination was obtained using the levels and parameters. Anawa [4] used Taguchi approach for $\mathrm{CO}_{2}$ continuous laser welding process. Dissimilar materials welding was carried out to understand the effect of three-process parameter in 5 levels on the weld penetration and bead width on the surface and mid depth section of the bead with $\mathrm{L}_{25}$ orthogonal array with satisfactory results. Aavanish [5] had summarized different $\mathrm{CO}_{2}$ and $\mathrm{Nd}$ : YAG laser processes and discussed different experimental methods used for process optimization including Taguchi methods.

Welding is conducted using gas laser welding. The major components of laser equipment are active medium, pumping mechanism and an optical resonator. Active medium or gain medium, next to the population inversion system, where laser action of stimulated emission is established. In the pumping mechanism, the molecules at lower energy level are pumped into higher energy levels. Finally, in the optical resonator Laser welding simulation was used in the recent past to understand and evaluate and predict (distortion and residual stresses) the performance of weld for different input parameters [6-10]. S. Bandyopadhyay et al. [11] have applied Taguchi analysis for Laser drilling and process optimization was done to obtain diameter from the entry to exit with the desired taper with minimum splatter. Welding process is documented by many researchers from experimental, design simulation and analysis. All welding studies need to see the thermal material 
properties, the heat flux generation by the process selected, rate of welding and if any cooling and environment protection and chemical protection is used like Argon gas as is done in the laser Akella et al, [12,13] who have defined distortions in longitudinal, along the weld and transverse along the transverse directions and applied Taguchi methods to TIG welding processes.

Phillip J Ross [14] has given different Taguchi methods for beginners and is widely used in industry. Various aspects of Taguchi methods $[15,16]$ were used to make the analysis useful for designers and engineers to use them. Taguchi has defined online and offline analysis. He has three steps in achieving robustness: system design, parameter design and tolerance design. The objective of this study is to minimize the transverse distortion when $3 \mathrm{~mm}$ thick plates of SS316LN are welded by the laser beam. In this study confirmation interval, process capability and tolerance design were calculated. It has defined the offline application of Taguchi methods during the design stage which is most important for any new model or process. In the present study, stainless steel 316 material used in nuclear fusion reactors is analyzed for welding properties specially distortion studies. L 9 Taguchi experimentation was done using laser welding process and distortion measured. The three levels of three parameters, laser power, and welding speed and argon flow rate were optimized with Anova and pooled ANOVA techniques.

\section{EXPERIMENTAL WORK}

Welding was done after establishing the fixtures and equipment for stability, consistency and uniformity so that the noise factors were minimized. In this experiment, no repetitions could be done as the availability of parts was limited because it was basic evaluation only. Therefore, $\mathrm{S} / \mathrm{N}$ analysis of the signal to noise ratio analysis is not part of the study. An L 9 Orthogonal array of experimentation is chosen to understand the criticality of three parameters [16]; Laser Power, Welding Speed, and Argon Flow rate as the parameters.

Electric discharge by inelastic atom-atom collisions of gas medium, amplification of beams is obtained to provide laser heat source required for welding of parts. Experiments of welding with $3 \mathrm{~mm}$ thick plates of $150 \mathrm{~mm}$ length and $300 \mathrm{~mm}$ width were welded with Laser beam weld machine, Figure 1(a). The Laser beam machine was set with beam diameter of $2 \mathrm{~mm}$, and beam focus at $90^{\circ}$ angle for all the experiments. The $\mathrm{L}_{9}$ orthogonal array is selected for the experimentation with three levels for each of the parameters shown in Table 1. The Factors and levels were selected taking into consideration the criticality of the factors. Implementation difficulty and the cost were accommodated. Here, 3 levels (Level-1, Level-2 and Level-3) were defined for each parameter to take into account any nonlinearity effect.

There are three levels for each of the parameters shown in Table-2. The Orthogonal Array of 9 experiments $\mathrm{L}_{9}$, are shown in Table- 3 . $\mathrm{L}_{9}$ provides the option of taking three parameters of each factor, three columns of 2 degrees of freedom are provided for three factors and the last column is left for error. This is a fractional factorial experimentation an Orthogonal Array. The $\mathrm{L}_{9}$ experiments will give statistical data of full factorial experiments. Conducting full factorial experiments is difficult and maintaining the accuracy would be expensive with a possible loss in data. Welded parts are shown in Figure-1. $\mathrm{L}_{9}$ types of laser welding samples were tested for distortion using a calibrated dial gauge and flat measurement table.

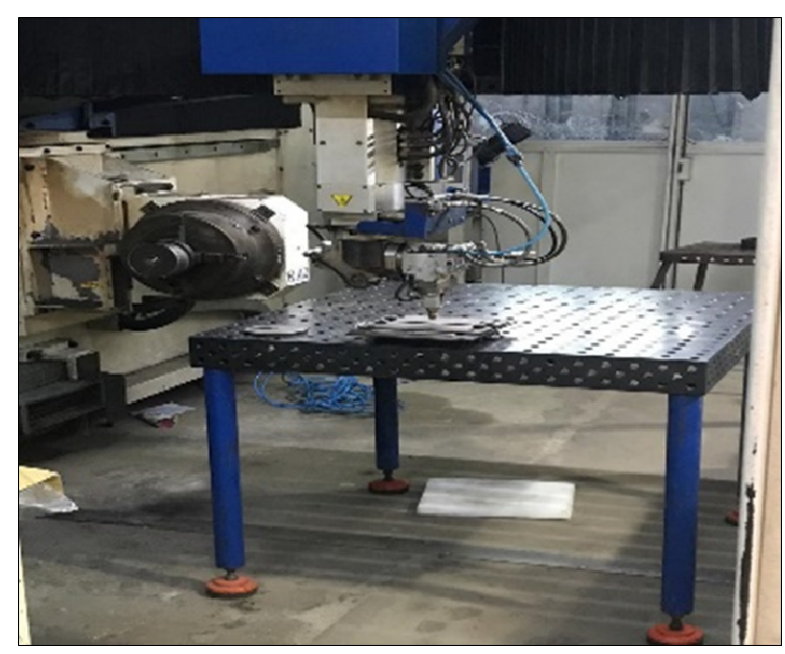

Figure 1. (a) $\mathrm{CO}_{2}$ Laser welding machine

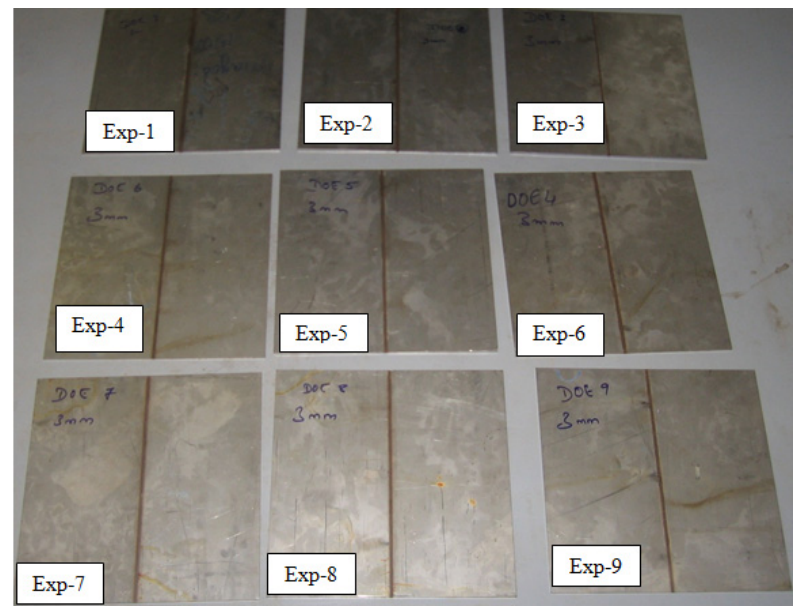

Figure 1. (b) Welded experimental parts as per L9 design of experiments

Table 1. $L_{9}\left(3^{4}\right)$ Orthogonal Array

\begin{tabular}{|c|c|c|c|c|}
\hline \multirow{2}{*}{ Trial no } & \multicolumn{4}{|c|}{ Welding parameter levels } \\
\cline { 2 - 5 } & $\mathrm{A}$ & $\mathrm{B}$ & $\mathrm{C}$ & $\mathrm{D}$ \\
\hline 1 & 1 & 1 & 1 & 1 \\
\hline 2 & 1 & 2 & 2 & 2 \\
\hline 3 & 1 & 3 & 3 & 3 \\
\hline 4 & 2 & 1 & 2 & 3 \\
\hline 5 & 2 & 2 & 3 & 1 \\
\hline 6 & 2 & 3 & 1 & 2 \\
\hline 7 & 3 & 1 & 3 & 2 \\
\hline 8 & 3 & 2 & 1 & 3 \\
\hline 9 & 3 & 3 & 2 & 1 \\
\hline
\end{tabular}

Table 2. Factors and levels for L9 experiment

\begin{tabular}{|l|c|c|c|c|}
\hline Factors & Units & L-1 & L-2 & L-3 \\
\hline A, Laser power & W & 1500 & 1750 & 2000 \\
\hline B, Welding speed & $\mathrm{mm} / \mathrm{min}$ & 2500 & 3000 & 3500 \\
\hline C, Argon flow rate & LPM & 10 & 15 & 20 \\
\hline
\end{tabular}


Table 3. $L_{9}$ Experiments for Laser welding

\begin{tabular}{|c|c|c|c|}
\hline Trails & Laser Power & $\begin{array}{l}\text { Welding } \\
\text { Speed }\end{array}$ & $\begin{array}{l}\text { Argon } \\
\text { Flow rate }\end{array}$ \\
\hline 1 & 1500 & 2500 & 10 \\
\hline 2 & 1500 & 3000 & 15 \\
\hline 3 & 1500 & 3500 & 20 \\
\hline 4 & 1750 & 2500 & 15 \\
\hline 5 & 1750 & 3000 & 20 \\
\hline 6 & 1750 & 3500 & 10 \\
\hline 7 & 2000 & 2500 & 20 \\
\hline 8 & 2000 & 3000 & 10 \\
\hline 9 & 2000 & 3500 & 15 \\
\hline
\end{tabular}

\section{RESULTS AND DISCUSSIONS}

Experiments were randomized in the $\mathrm{L}_{9}$, DOE, to avoid bias that might arise, due to uncontrolled noise factors, causing errors. The objective was to obtain the optimized levels in each of the parameters that would result in least distortion. Factors and levels were maintained to make the experiments orthogonal, so that each experiment is independent. From the Linear Figures, a visual comparison indicates Level 3 for factor A, Level 1 for factor $\mathrm{B}$ and level 3 for factor $\mathrm{C}$ give the least distortion. Their criticality can be seen only through ANOVA.

\subsection{Parametric study}

The first step when data is put in Tabular form as in Table-4 is evaluation by method of ranking. As distortion is lower the better, we observe that the $7^{\text {th }}$ trial gave the least distortion. The factors are allotted to the first three columns of the $L_{9}$, table and Column D is left to evaluate the errors. Least distortion is observed in Experiment 7, Power at level-3, 2000W; Welding speed, $2500 \mathrm{~mm} / \mathrm{min}$; at level-2 and Argon flow rate at 20LPM, level-3; resulted in $0.98 \mathrm{~mm}$ distortion. The worst is experiment 2, Power at level 1, 1500W; welding speed at level-2, 3000mm/min; and Argon flow rate at level-2, 15LPM. with $1.45 \mathrm{~mm}$ distortion.

Table 4. $L_{9}$ Experiments for Laser welding

\begin{tabular}{|c|c|c|c|c|c|}
\hline Trails & $\begin{array}{c}\text { Laser } \\
\text { Power }\end{array}$ & $\begin{array}{c}\text { Welding } \\
\text { Speed }\end{array}$ & $\begin{array}{c}\text { Argon } \\
\text { Flow } \\
\text { rate }\end{array}$ & Error & Distortion \\
\hline 1 & 1500 & 2500 & 10 & e1 & 1.15 \\
\hline 2 & 1500 & 3000 & 15 & e2 & 1.45 \\
\hline 3 & 1500 & 3500 & 20 & e3 & 1.21 \\
\hline 4 & 1750 & 2500 & 15 & e3 & 1.303 \\
\hline 5 & 1750 & 3000 & 20 & e1 & 1.193 \\
\hline 6 & 1750 & 3500 & 10 & e2 & 1.22 \\
\hline 7 & 2000 & 2500 & 20 & e2 & 0.981 \\
\hline 8 & 2000 & 3000 & 10 & e3 & 1.291 \\
\hline 9 & 2000 & 3500 & 15 & e1 & 1.39 \\
\hline
\end{tabular}

One of the advantages of Orthogonal Analysis, OA, is putting the main factors, parameters affect in graphical form for a quick visual decision. Selection is based on lower the better for distortion after welding of a part. From figure 2 level 3, 2000 Watts power is the best. Similarly, for welding speed, level 1, 2500mm.min is the best which gives a distortion of $1.15 \mathrm{~mm}$ as in figure 3. From figure 4 level 3, 20 LPM Argon flow is the best for distortion of $1.13 \mathrm{~mm}$. From linear figure, individual best levels are obtained. However, to know if they have statistical significance, Analysis of Variance is required to be done. ANOVA.

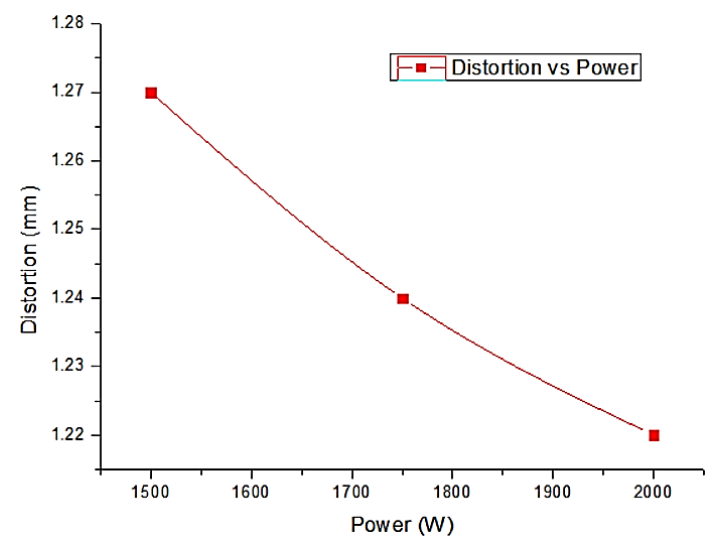

Figure 2. Best level of Laser Power Parameter

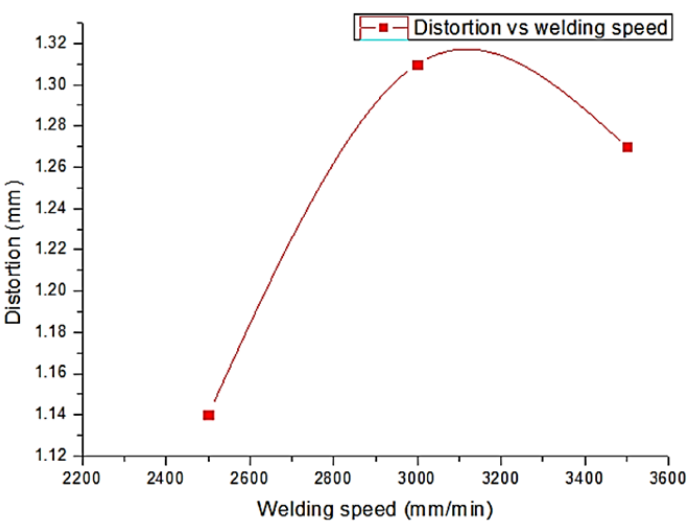

Figure 3. Best level of Welding Speed Parameter

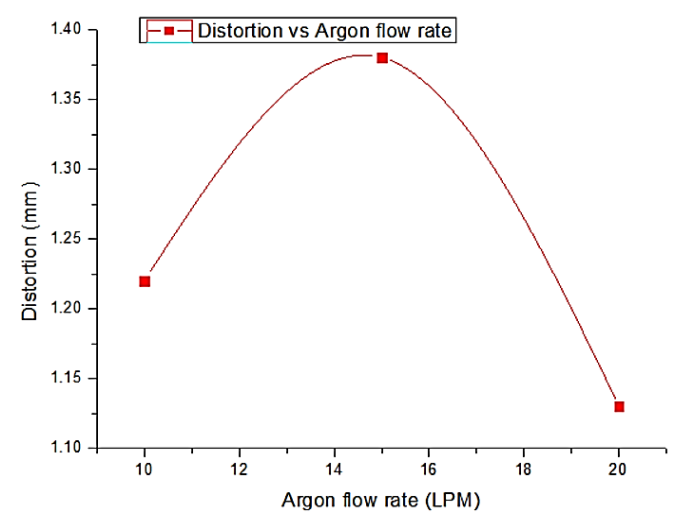

Figure 4. Best level of Argon Flow Rate Parameter

\subsection{No-Way ANOVA}

From the output, distortion, data of $\mathrm{L}_{9}$ experiments, two lines are possible as plotted in No-way ANOVA as shown in Figure 5. It is called no way as no parameter is referred in this evaluation, only the variation of the data is seen from its mean value, which always a straight line. The second line is the variation of the distortion as seen from the mean value in the 9 experiments. For well-selected parameters, a wide variation from the mean is expected which ensures that the selected parameters are critical. 


\begin{tabular}{|l|l|l|l|l|l|l|l|}
\hline Source & SS & DOF & Variance & F, Expt & F.9.1,8 & F.95.1.8 & F.99,1,8 \\
\hline Mean & 13.91 & 1 & 13.9079 & 8.91653 & 3.46 & 5.32 & 11.3 \\
\hline Error & 0.13 & 8 & 0.01628 & 0.01043 & & & \\
\hline Total & 14.04 & 9 & 1.55979 & & & & \\
\hline
\end{tabular}

Table 6: ANOVA compare with error

\begin{tabular}{|l|l|l|l|l|l|l|l|l|}
\hline Source & SS & DOF & Variance & F, Expt & F.01,22 & F.05,2,2 & f.01,2,2 & $\begin{array}{c}\% \\
\text { Contribution }\end{array}$ \\
\hline F-table & & & & & 9.0 & 19.0 & 99.0 & \\
\hline Laser Power, W & 0.004 & 2 & 0.00187 & 0.956843 & & & & 2.5 \\
\hline Welding Speed, mm/S & 0.046 & 2 & 0.02289 & 11.71297 & & & & 30.2 \\
\hline Argon flow rate, LPM & 0.098 & 2 & 0.04917 & 25.16444 & & & & 64.8 \\
\hline Error & 0.004 & 2 & 0.00195 & & & & & 2.5 \\
\hline Total & 0.152 & 8 & 0.01897 & & & & & \\
\hline
\end{tabular}

Table 7: Pooled ANOVA

\begin{tabular}{|l|l|l|l|l|l|l|l|l|}
\hline Source & SS & DOF & Variance & F, Expt & F.9,2,4 & F.95,2,4 & F.99,2,4 & $\begin{array}{c}\% \\
\text { Contribution }\end{array}$ \\
\hline F-Table & & & & & 4.32 & 6.94 & 18 & \\
\hline Welding Speed, mm/S & 0.05 & 2 & 0.023 & 11.713 & & & & 30.1 \\
\hline Argon flow rate, LPM & 0.1 & 2 & 0.049 & 25.164 & & & & 64.7 \\
\hline Error & 0.01 & 4 & 0.002 & & & & & 5.2 \\
\hline Total & 0.15 & 8 & 0.019 & & & & & \\
\hline
\end{tabular}

Table 8: Confidence interval for critical parameters

\begin{tabular}{|c|c|c|c|c|c|c|c|}
\hline \multicolumn{8}{|c|}{ Estimated variation of Levels at 90\% confidence } \\
\hline Welding Speed & Lower & Mean & Higher & Argon Flow rate & Lower & Mean & Higher \\
\hline B1 & 1.2 & 1.09 & 1.145 & C1 & 1.275 & 1.165 & 1.22 \\
\hline B2 & 1.366 & 1.256 & 1.311 & C2 & 1.436 & 1.326 & 1.381 \\
\hline B3 & 1.328 & 1.218 & 1.273 & C3 & 1.183 & 1.073 & 1.128 \\
\hline
\end{tabular}

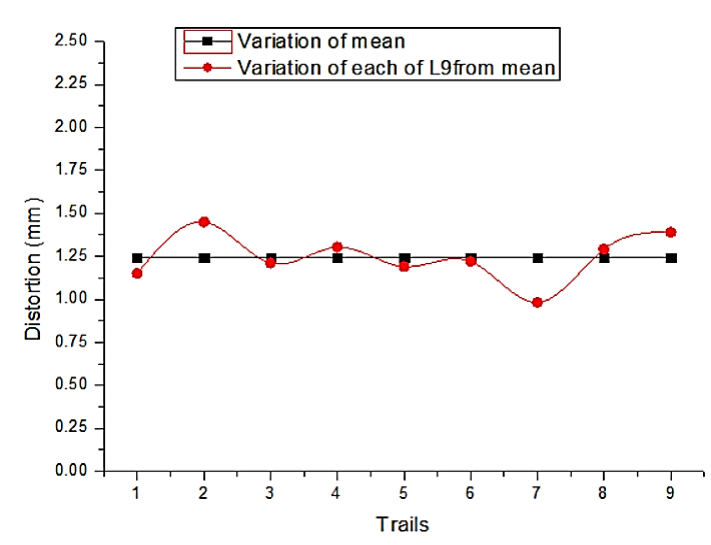

Figure 5: Variation about the mean

As shown in Table 5 the check of significance is between the variations from mean to the $\mathrm{F}$ values. The experimental $\mathrm{F}$ value, 8.916 is compared with the tabular Fischer, F value and is significant if it is higher. Three $\mathrm{F}$ values are given, 3.46 is for $90 \%$ significance, 5.32 for $95 \%$ significance and 11.3 is for $99 \%$ significance. As 8.916>5.32 these experimental values have critical parameters with a confidence of $95 \%$, and we may do full ANOVA. In No-way ANOVA Table 5.

Two factors are significant. Welding speed F, Expt is $11.7>9.0$, F-Table, therefore this is a critical factor of $90 \%$ confidence. In the case of the Argon flow rate, FExpt, $25.16>19$. Moreover, hence parameter is significant with $95 \%$ confidence. Significance denotes that the averages belong to different populations. By pooling the power into error, we get pooled ANOVA, Table 6. Here, the error dof increase to 4 . The variance changes to 0.002 and also the $\mathrm{F}$ table values change. The Significance by comparing F-expt., F-Table gives the same significance with no confidence level change. Percentage contribution tells the importance of the factor in the control of the output in this case distortion. \% contribution is obtained by the ration of the individual sum of squares by the total sum of squares. In the ANOVA table the last column shows the contribution. Laser power contributes only $2.5 \%$ of the change in welding speed has a contribution of $30.1 \%$ of the variation in distortion and Argon flow rate $64.7 \%$. To make error larger allows more stability to analysis and gives more confidence, for the same Power is added to error contribution in the pooled analysis.

\subsection{Analysis of Variance, ANOVA:}

From full Anova we would like to evaluate the significance of each of the three parameters, factors that are chosen for significance in their contribution to controlling of the output parameter, distortion. In this method mean is included in the calculations and is not shown as a parameter. In ANOVA, individual factor contribution is calculated as the sum of squares and using degrees of freedom variance is calculated, Table 6. In making ANOVA table two statistical tools are used, central limit theorem and F test.

\section{Central Limit theorem:}

First, the central limit theorem which says that the variance of sample averages is less than the variance of the distribution of the individuals. Suppose, factor A 
sum of squares, $\mathrm{SS}_{\mathrm{A}}$, is to be found for a 3level factor without repetitions, na $1=$ na $2=$ na $3=3$, where na- 1 is a number of experiments with factor $\mathrm{A}$ at first level. Similarly, na2 and na3:

$$
\mathrm{SS}_{\mathrm{A}}=\frac{\left(\mathrm{A}_{1}\right)^{2}}{3}+\frac{\left(\mathrm{A}_{2}\right)^{2}}{3}+\frac{\left(\mathrm{A}_{3}\right)^{2}}{3}
$$

Where A1, A2 and A3 are the sums of the observations with each of these levels. Here $\mathrm{A} 1=3.81$, $\mathrm{A} 2=3.72$ and $\mathrm{A} 3=3.66$. Similarly, for factor $\mathrm{B}, \mathrm{SSB}$ and for factor C SSC can be found. The total sum of squares, SST, is defined as:

$$
\mathrm{SS}_{\mathrm{T}}=S \text { ni } \mathrm{y}^{2} \mathrm{i}-\frac{\mathrm{T}^{2}}{\mathrm{n}}
$$

Error sum of square, SSE can be found as

$$
\mathrm{SS}_{\mathrm{E}}=\mathrm{SS}_{\mathrm{T}}-\mathrm{SS}_{\mathrm{A}}-\mathrm{SS}_{\mathrm{B}}-\mathrm{SS}_{\mathrm{C}}
$$

Similarly, degrees of freedom, dof, are related. A 3level factor has 2 degrees of freedom, donating one dof to mean. Similarly, total degrees of freedom of L9, with 9 experiments is 9 and deleting one for mean results in 8 total degrees of freedom, vT. Each column of $\mathrm{L}_{9}$ experiment have 3 levels, only 3 of the 4 columns are allotted, and the $4^{\text {th }}$ column is attributed to error.

\section{F test for variance comparison:}

A critical parameter is statistically validated in ANOVA by $\mathrm{F}$ test, Ronald Fischer. Here, the variance of a factor is compared with the error variance to obtain the experimental $\mathrm{F}$ value. For say, factor $\mathrm{A}$ if VA is a variance of factor $\mathrm{A}$ and $\mathrm{VE}$ is a variance of error, then $\mathrm{F}$ value from the experiment is given as F, Expt $=$ $\mathrm{VA} / \mathrm{VE}$ which is a ratio of two sample variances. Also, from $\mathrm{F}$ table values are obtained for risk .1 or .05 or .01 corresponding to confidence $90 \%, 95 \%$ and $99 \%$. Corresponding to the numerator, factor, dof 2 and denominator, error, dof also 2 for ANOVAs in Table 3. and 4 for pooled ANOVA in Table 7. In F, variance, test If F-Expt $>$ F-Table value it is a significant critical value for the output observation.

Pooled Anova is a modified Anova where the noncontribution factors to the output are pooled with the error to increase contribution so that the overall evaluation of the significance of parameter evaluation is more meaningful. With the addition of power, total error contribution increases to about 5.2\%. Argon flow rate contributes about $64 \%$ of the distortion and welding speed about $30.1 \%$.

The design of the experiment is successful as about $95 \%$ of contribution is allotted to and error contribution being about $5.2 \%$ denotes controlled experimentation. The application of this study would be to the manufacturer who would like to know the process capability to meet the design requirement with this optimized process. With an assumed range of specifications compared with the control limits the process capability came to be 1.48 which will assure $3 \sigma$, capability. The final step in the analysis is to estimate the conformation interval for estimated mean and range. The process with optimized B1and C3 levels gives an estimated mean of $1.03 \mathrm{~mm}$ distortion.
For $90 \%$ confidence, the interval is 0.0318 and for $95 \%$ confidence the interval is 0.0414 . This interval can also be calculated for factors such as welding speed in Figure 6. Moreover, Argon flow rate in Figure 7. From these Figures, non-linearity of the distortion is indicated if robustness is required in future work this property can be exploited. Also, there is little overlap of a range of intervals of levels, which indicates that the individual level selection is satisfactory.

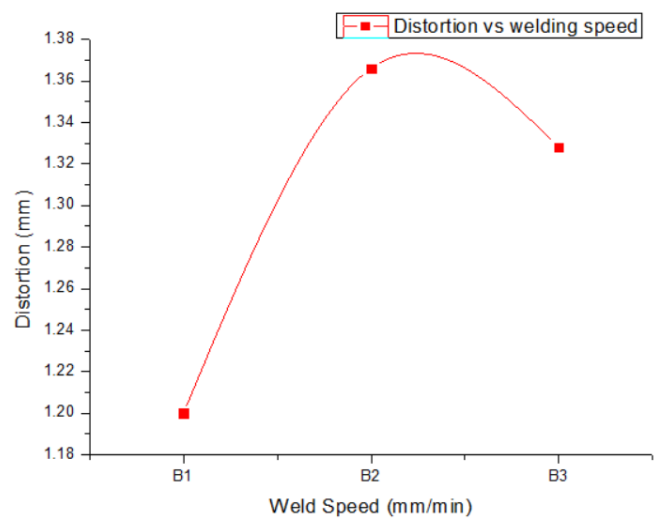

Figure 6: Estimated distortion due to Welding speed

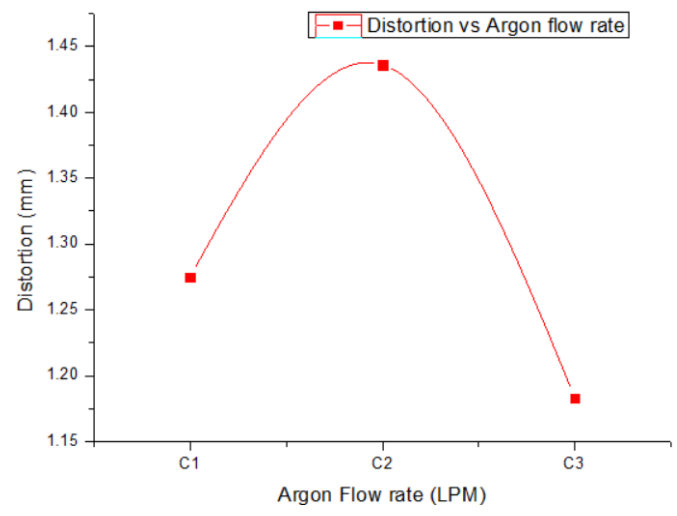

Figure 7: Estimated distortion due to Argon Flow Rate

As the material was consumed making confirmatory tests with optimized levels beyond the present scope. conservative comparison with all 3 levels of $\mathrm{C} 3$; experiments 3, 5 and 7 was done. The distortions are 1.21, 1.19 and 0.98 giving an average of 1.12 . This will be the upper limit as the second critical parameter with $31 \%$ contribution is not maintained. If both parameters are maintained as in experiment 7 with $0.98 \mathrm{~mm}$, distortion is possible. The final pooled ANOVA table gives \% contribution of each of the factors, for factor welding speed, B, it is $30.1 \%$; for Argon flow rate, C, it is 64.7 and error with factor power, A, pooled is $5.2 \%$. These factors have criticality of influence on distortion proportional to the percentage contribution.

\subsection{Estimation of Confidence Intervals}

Design of Experiments, DOE, ends with a confirmation test. As a fractional factorial without repetitions is done, confounding, confusion, uncertainty is possible. In manufacturing a product or a process; a mistaken experimental conclusion, may not result in expected improvement, if taken to large scale production, and hence a confirmation experiment is planned. 
- A preferred combination is B1, C3 (Welding speed, level 1, 2500 $\mathrm{mm} / \mathrm{min}$ and Argon flow rate 20LPM.)

- $\quad$ Estimated mean, $\mu \mathrm{B} 1 \mathrm{C} 3=B 1 A v g+C 3 A v g-\bar{T}$

$=1.145+1.128-1.243=1.03$. which is lower than the average of all experiments of 1.24.

- Estimate of pooled $\mathrm{SD}=\sigma \mathrm{p}=\sqrt{\operatorname{Pooled}(V e)}=$ $\sqrt{0.002}=0.045$

- Confidence Interval about the estimated mean: $\mathrm{CL}=\sqrt{\frac{F \cdot 1,1,4^{*} V e p}{n}}, \mathrm{~F}$ factor is taken at risk $\alpha$, is .1 and Confidence is .9. 1 is dof of mean and 4 is dof of errors. $V_{\text {ep }}$ is pooled error, $n$ is number $r$ of trials.

$$
\begin{aligned}
& \circ \mathrm{CI}(90 \%)=\sqrt{\frac{4.54 * 0.002}{9}}=0.0318 \\
& \circ \mathrm{CI} 2(95 \%)=\sqrt{\frac{7.71 * 0.002}{9}}=0.0414
\end{aligned}
$$

- The confidence interval can be applied to each level of each factor where $n=3$, experiments for each level. $\mathrm{Cl} 3=\sqrt{\frac{4.54 * 0.002}{3}}=0.055$.

- $\quad$ Estimated levels of critical Factors of Welding speed and Argon Flow Level is given in Table 8. And the same are shown in Figure 6 and 7.

\subsection{Tool material and design}

The process Capability of Distortion with the parameters selected can be calculated from the error variance $\mathrm{Ve}=\mathrm{SS}_{\mathrm{E}} /$ error dof. The process control of Upper and lower limits is determined and the process capability is determined if the specification limits are defined within these limits.

- $\quad$ Estimated mean, $\mu \mathrm{B} 1 \mathrm{C} 3=$

$B 1 \mathrm{Avg}+\mathrm{C} 3 \mathrm{Avg}-\bar{T}=1.145+1.128-1.243=1.03$

- Estimate of pooled $\mathrm{SD}=$

$\sigma p=\sqrt{\text { pooled }(V e)}=\sqrt{0.002}=0.045$

Lower process control limit is $\mathrm{LCL}=-3 \sigma \mathrm{p}$ : 1.03$3 * 0.045=0.895 \mathrm{~mm}$, Upper process capability limit is $+3 \sigma: 1.03+3 * 0.045=1.165 \mathrm{~mm}$,

Process range $=(U C L-L C L)=0.27 \mathrm{~mm}$

If, Lower specification limit, LSL is $0.8 \mathrm{~mm}$ and Upper specification limit, USL is $1.2 \mathrm{~mm}$, then the process capability, $\mathrm{Cpk}$, is =Specifications range/ Control Range

$$
\begin{aligned}
C p k & =((U S L-L S L) /(U C L-L C L)) \\
& =(1.2-0.8) /(1.165-0.895)=1.48 .
\end{aligned}
$$

This is a good process capability, when Cpk $>1,3 \sigma$ process capability is obtained and when $\mathrm{Cpk}>2,6 \sigma$ process capability is obtained. On the other hand, if specifications are narrower then this process may not be suitable, Modifications will be required with lower mean and narrower standard deviation.

\section{CONCLUSION}

$\mathrm{L}_{9} \mathrm{OA}$ experiments were done to find experimental by the best factor combination for least distortion in laser welding of SS304 plates.

- It is found that experiment 7 with Power at 2000, welding speed at $2500 \mathrm{~mm} / \mathrm{min}$ and Argon flow rate at 20LPM will give $0.98 \mathrm{~mm}$ distortion, with about $95 \%$ confidence.

- Welding power is not a significant factor, keeping it at a lower value of $2000 \mathrm{~W}$ will help in cost reduction without sacrificing quality.

- Argon flow rate is most significant and then welding speed. These two contribute about $95 \%$ of the distortion. Various aspects of the Taguchi method [14] were used to make the analysis useful for designers and engineers to use the results.

- Estimation of confidence interval predicts a variation in distortion from 0.98 by 0.0414 with 95\% confidence.

\section{REFERENCES}

[1] Subashini, L., Prabhakar, K. V. P., Gundakaram, R. C., Ghosh, S., and Padmanabham, G.: Single Pass Laser-Arc Hybrid Welding of Maraging Steel Thick Sections, Materials and Manufacturing Processes, vol. 31, No. 16, pp. 2186-2198, 2016.

[2] Ruan, X., Zhou, Q., Shu, L., Hu, J., and Cao, L.: Accurate Prediction of the Weld Bead Characteristic in Laser Keyhole Welding Based on the Stochastic Kriging Model, Metals, vol. 8, No. 7, p. 486, 2018.

[3] Pan, L. K., Wang, C. C., Hsiao, Y. C., and Ho, K. C.: Optimization of $\mathrm{Nd}: \mathrm{YAG}$ laser welding onto magnesium alloy via Taguchi analysis, Optics and Laser Technology, volume 37, No. 1, pp. 33-42, 2005.

[4] Anawa, E. M., and Olabi, A. G.:Using Taguchi method to optimize welding pool of dissimilar laser-welded components, Optics and Laser Technology, vol. 40, No. 2, pp. 379-388, 2008.

[5] A. K. Dubey and V. Yadava.: Experimental study of Nd:YAG laser beam machining-An overview, Journal of Materials Processing Technology, vol. 195, No.1-3, pp. 15-26, 2008.

[6] A. P. Mackwood and R. C. Crafer.: Thermal modelling of laser welding and related processes: a literature review, Optics and Laser Technology, vol. 37, No. 2, pp. 99-115, 2005.

[7] L. Mugwagwa, D. Dimitrov, S. Matope, and I. Yadroitsev.: Influence of process parameters on residual stress related distortions in selective laser melting, Procedia Manufacturing, vol. 21, pp. 9299, 2018. 
[8] D. Deng and H. Murakawa.: Prediction of welding distortion and residual stress in a thin plate buttwelded joint, Computational Materials Science, vol. 43, No. 2, pp. 353-365, 2008.

[9] G. A. Moraitis and G. N. Labeas.: Residual stress and distortion calculation of laser beam welding for aluminium lap joints, Journal of Materials Processing Technology, vol. 198(1-3), pp. 260 269, 2008.

[10]A. Kaplan.: A model of deep penetration laser welding based on calculation of the keyhole profile, Journal of Physics D: Applied Physics, vol. 27, No. 9, pp. 1805-1814, 1994.

[11] S. Bandyopadhyay, H. Gokhale, J. K. Sarin Sundar, G. Sundararajan, and S. V. Joshi.: A statistical approach to determine process parameter impact in Nd:YAG laser drilling of IN718 and Ti-6Al-4V sheets, Optics and Lasers in Engineering, vol. 43, No.2, pp. 163-182, 2005.

[12] H. Vemanaboina, G. Edison, S. Akella.: Distortion control in multi pass dissimilar GTAW process using Taguchi ANOVA analysis, International Journal of Engineering and Technology, vol. 7, No. 3, p. 1140-1144, 2018.

[13] Harinadh Vemanaboina, G. Edison, Suresh Akella and Ramesh Kumar Buddu.: Simulation of Hybrid Laser-TIG Welding Process Using FEA, Journal of Engineering Science and Technology, vol. 13, No. 6,1782 - 1792, 2018.

[14] Phillip J Ross, Taguchi Techniques for Quality Engineering, Tata Mc Graw Hill, 2008.

[15] Genichi Taguchi and $\mathrm{Yu}$ in $\mathrm{Wu} .:$ offline quality, Central Japan quality Control Association, Nagaya, pp30-31, 1979.

[16] S. Marichamy, M. Ravichandran, B. Stalin, and S. Babu, "Optimization of abrasive water jet machining parameters for $\alpha-\beta$ brass using Taguchi methodology," FME Transactions, vol. 47, no. 1, pp. 116-121, 2019.

\section{NOMENCLATURE}

\section{Superscripts}

ANOVA Analysis of Variance

HAZ Heat Affected Zone

DOE Design of Experiments

TIG Tungsten Arc Welding

S/N Signal to Noise Ratio

LPM Litre Per Minute

OA Orthogonal Array

\section{КОНТРОЛА ДИСТОРЗИЈЕ КОД ЗАВАРИВАЊА ЛАСЕРОМ ПРИМЕНОМ ТАГУЧИ МЕТОДЕ И АNOVА АНАЛИЗЕ}

\section{Х. Вемабоина, С. Акела, Р.К. Буду}

Контрола индустријског процеса је од значаја јер купци постављају све веће захтеве у погледу квалитета, цене, перформанси и поузданости производа. У циљу постизања минималне дисторзије после заваривања ласером, применом Тагучијевог плана експеримената са фракционим факторијалним дизајном обављено је девет произвољно одабраних контролисаних испитивања са заваривањем ласером уз коришћење три параметра: снагу ласера, брзину заваривања и брзину протока аргона. Сваки фактор је имао три степена слободе а фракциона факторијална анализа је примењена у циљу изналажења најбоље комбинације нивоа параметара контроле дисторзије, што је нижи ниво, утолико је мања дисторзија. Коришћени су следећи параметри: методе једноставне инспекције, једнофакторијална ANOVA, линеарне вредности, ANOVA и мултиваријациона ANOVA. Утврђено је да су два најзначајнија фактора брзина заваривања $31 \%$ и брзина протока аргона $68 \%$ са статистичким нивоом поверења 90-95\%. Трећи фактор је био фактор минималних трошкова за који је утврђено да није био од значаја за контролу дисторзије. Примењени су различити аспекти Тагучијеве методе јер се сматрало да могу бити од користи дизајнерима и инжењерима. Интервал поверења, капацитет процеса и планирање толеранција су израчунати. 